\title{
Economic development versus the growing im- portance of the financial sector: Global insight
}

\author{
Marek Maciejewski, Agnieszka Głodowska
}

\begin{abstract}
A B S T R A C T
Objective: The objective of the article is to show the relationship between the growing role of the financial sector and economic development in the context of the 4 Industrial Revolution (4IR).

Research Design \& Methods: The article uses linear ordering based on the standardized sums method. It allowed for the construction of a synthetic indicator of the financialisation of the economy. The values of this indicator were compared with the GDP growth rate of selected countries.
\end{abstract}

Findings: Studies have shown that, for the countries with the highest economic development level, there is no reason to say that too high level of development in the financial sector slows down their economic growth. Instead, it turned out that the development of the financial sector, which is detrimental to economic growth, occurs in countries in transition and those with an average economic development level. There the level of financialisation of the economy is lower.

Contribution \& Value Added: The study was carried out on a large group of countries with different economic development levels, making it possible not only to draw general conclusions but also to address individual countries' specificities.

\begin{tabular}{|c|c|}
\hline Article type: & research paper \\
\hline Keywords: & $\begin{array}{l}\text { financial sector; financialisation; economic development; } 4 \text { Indus- } \\
\text { trial Revolution; innovation }\end{array}$ \\
\hline JEL codes: & $\mathrm{G} 15, \mathrm{O} 10,030$ \\
\hline
\end{tabular}

\section{Suggested citation:}

Maciejewski, M., \& Głodowska, A. (2020). Economic development versus growing importance of the financial sector: Global insight. International Entrepreneurship Review (previously published as International Entrepreneurship / Przedsiębiorczość Międzynarodowa), 6(3), 77-90. https://doi.org/10.15678/IER.2020.0603.06 


\section{INTRODUCTION}

The modern industrial revolution is a natural process that progresses due to technological achievements to date that have emerged in social and economic systems. It is called the fourth industrial revolution (4IR). The first industrial revolution used water and steam to mechanize production. The second industrial revolution used electrical energy to create mass production, assembly lines, and labour division. The third industrial revolution, in turn, involved the development of semiconductors, information technologies (ITs), and personal computers. The new fourth technological revolution is based de facto on the technologies and infrastructure developed in the third phase of the process but uses them in a completely new way, one in which technologies become an integral part of the daily functioning of societies and economies (Liu, 2017). Although Schwab and Davis (2018) point out that we are only in its initial phase, the advanced virtualization and digitization have caused unprecedented social and economic changes.

The financial sector is considered to be most affected by innovation (Karabay \& Cağil, 2017). The growing dependence of financial market players on complex financial innovations is characteristic of the recent universal financialisation trend. In particular, it contributes to changes in financial services technology, trading of financial instruments, information transfer, financial risk perception, and the role of financial intermediation (Bilan et al., 2019). The causes of this process are known, but the effects are not clearly assessed. The experience of various economies, especially in the global financial crisis, casts doubt on the validity of using controversial technological solutions in the financial sector. Therefore, it raises a question about the strength and direction of the financial market's impact on the real economy. Does the financial sector stimulate economic growth by nature or only under certain conditions, which may concern the level of economic development or the financial sector's maturity and innovation?

The pursuit of answering this research question leads to the realization of this article's primary objective: to show the relationship between the financial sector's growing role and its negative impact on the real economy. This research problem will be conducted based on the analysis of a broad group of countries with different economic development levels. First of all, the importance of technological progress in the development of financial markets is presented and the relationship between the financial market and economic development. In the analytical part we use linear ordering tool based on normalized sums and simple panel regression.

\section{LITERATURE REVIEW}

\section{Industrial Revolution and the Financial Sector}

The term fourth industrial revolution (4IR) was first used in the Schwab publication (2016) to describe the next phase of the impact of emerging modern technologies on all areas of human activity in the early 21 st century. As the name suggests, it is already another revolution taking place in society's systems, gradually changing the complex realities between man and technology and transfers that result in a new way of acting and functioning (Philbeck \& Davis, 2019). Three fundamental planes are identified as the source of the 
driving forces behind today's dynamic technological changes, among which the most important is digitalization (Schwab, 2016): 1) the physical plane (advanced robotics, autonomous vehicles, 3D printers, new materials), 2) the biological plane (biotechnology, neuroethology, genomics), 3) the digital plane (artificial intelligence, the Internet of Things, Blockchain, digital clouds, big data, virtual reality).

As a kind of universalism, it is assumed that the technological revolution has affected virtually all social and economic life areas. Literature is becoming increasingly rich in studies on the impact of this revolution on economic growth and sustainable development (Lucas, 2009; Davis \& Sener, 2012), foreign trade (Bloom et al. 2016; Rymarczyk, 2020), international relations (Philbeck \& Davis, 2019; Rymarczyk, 2020) and the financialisation of the economy (Kimani et al., 2019). It is not easy to talk about these areas separately. It is evident that $4 \mathrm{IR}$ contributed the most to technological and financial innovations (Li et al., 2021). Frame and White (2004) and Karabay and Cağil (2017) state that the financial sector is the most innovative in the world. The industrial revolution in the financial market is a process enforced by both the demand and the supply sides. Growing customer expectations drive the process of continuous change in the financial market. The regulatory environment, bank burdens (capital, liquidity, technology), and consumer protection pressures generate high financial institutions costs (PWC, 2014). The compilation of these factors encourages the "creative destruction" of innovation and the emergence of new players in the financial markets, such as Fintech, which initiates an increasing scale of financial services' digitalization. It has led to a situation where some solutions involving innovative financial technologies have become the only platform for performing operations and technological processes. What is more, technological innovations have become an important tool to compete in the financial market (Paskevicius \& Keliuotyte-Staniuleniene, 2018). As a result, new financing methods, virtual money (cryptocurrencies), and complicated algorithms for decision making, innovative entities (Bayón \& Vega, 2018) have emerged. The use of 4IR effects in the financial sector is shown in Table 1.

Table 1. Application of 4IR effects in the financial sector

\begin{tabular}{|l|c|c|c|c|c|}
\hline \multirow{2}{*}{\multicolumn{1}{c|}{ Digital Technology }} & \multicolumn{5}{c|}{ Financial Services } \\
\cline { 2 - 6 } & Payment & Advisory & $\begin{array}{c}\text { Investment \& } \\
\text { Trading }\end{array}$ & $\begin{array}{c}\text { Financing \& } \\
\text { Funding }\end{array}$ & Insurance \\
\hline Blockchain & $\checkmark$ & $\checkmark$ & $\checkmark$ & $\checkmark$ & $\checkmark$ \\
\hline Big data analytics & & & & & $\checkmark$ \\
\hline Artificial intelligence & & $\checkmark$ & $\checkmark$ & & \\
\hline Augmented reality & & $\checkmark$ & $\checkmark$ & & $\checkmark$ \\
\hline Virtual reality & & & & & $\checkmark$ \\
\hline Biometric & & & & & $\checkmark$ \\
\hline Internet of things & $\checkmark$ & & $\checkmark$ & $\checkmark$ & \\
\hline Cloud computing & & & $\checkmark$ & & $\checkmark$ \\
\hline
\end{tabular}

Source: adapted from Alan et al. (2019).

About the consequences of 4IR for the financial market, most of the studies are positive. After all, Schumpeter (1960) already combined entrepreneurship, innovation, and the financial product of credit into the necessary components of positive economic changes. The financial market determines the reallocation of savings from relatively less 
profitable investments to sectors with a higher rate of return (Schumpeter, 1960; Dębski \& Bujnowicz, 2007). Karabay and Çağil (2016) state that innovation is a noticeable feature of the modern economy's financial services sector. According to the authors, financial innovations increase existing participants' capacity and attract new market players who attract new and innovative products (Karabay \& Çağil, 2016). Continuous digitalization of financial services ensures their compatibility with the solutions used so far - gadgets and data analysis platforms provide the possibility of creating permanent and complex consumer solutions. It leads to a situation where specific innovations have become the only possible way of performing operations and technological processes. What is more, they have become a way of competing (Paskevicius \& Keliuotyte-Staniuleniene, 2018; Bilan et al. 2019). It means that the introduction of 4IR solutions to the financial sector not only benefits the industry itself but also serves the needs of society by making products or investments available to anyone who wants a higher rate of return (Li et al., 2021; Su et al., 2020). Examples of such solutions are cryptocurrencies, hailed as the most significant financial innovation of the century (Li et al., 2021). It is recognized that thanks to technological innovations (e.g., Blockchain), it is possible to conduct complex processes, which are only possible thanks to the applied technologies. They create a new strategic and market value: lowering transaction costs, increasing the pace of financial processes, increasing efficiency, enabling the reduction of fraud, increasing the transparency of operations, and eliminating the problem of information asymmetry (Nowiński \& Kozma, 2017; Lee \& Shin, 2018; Kiman et al., 2020).

Despite these many advantages of digitizing the financial sector, Koizumi (2019) speaks of the lights and shadows of 4IR. Thampanya et al. (2020), in turn, combine the effects of the industrial revolution with the recent global financial crisis, stating that they contribute to financial shocks. The proliferation of complex financial innovations such as asset securitization and new derivatives has weakened risk management solutions. They have led to a kind of risk dilution on the one hand, and on the other hand, they have eliminated the mechanism of limiting excessive risk-taking by banks. That has led to instability and a kind of polarization of innovative financial solutions (Judge, 2012; Głodowska, 2012; Pernell, 2020).

Similarly, Dai and Vasarhelyi (2017) assess blockchain technologies related to, e.g., cryptocurrencies, which the authors consider to be a highly advanced, knowledge-intensive technology, requiring appropriate IT skills and know-how by all those who are to some extent related to this technology. This complexity and opacity can lead to blindness for market participants, with the risk of overuse of these instruments (Iansiti \& Lakhani, 2017). Alam et al. (2019) talk about the digitalization and disruption of the financial market.

\section{Financial Sector and Real Economy}

The impact of the industrial revolution on the real economy can be assessed from both micro and macro perspectives. The implementation of $4 \mathrm{IR}$ effects becomes a key component of business strategies (Wang et al., 2020). It is also an essential factor in the international competitiveness of economies (Liu, 2017). However, it also carries risks and uncertainties. Innovation cannot be an aim in itself. That also applies to innovations in the financial sector, which are ultimately supposed to lead to increased efficiency, profitability, and competitive advantage, but at the same time contributing to the development of entire societies and economies. Only in this context did Schumpeter (1960) combine innovation and credit as the main economic driver. His creative destruction, which we can also 
refer to the financial market, is meant to transform and replace outdated solutions and mechanisms with new ones. Thus, perversely, it means destruction to create something more modern - better (Głodowska, 2019). Only by considering economic effects can the impact and legitimacy of 4IR in the financial sector be assessed.

The link between the financial market and the real economy is quite apparent. In theory, this was considered within the framework of neoclassical and endogenous concepts. The more effective the financial system, the higher the economy's savings and higher investments are leading to economic growth (Dębski \& Bujnowicz, 2007). Most empirical studies indicate a statistically significant relationship between these areas (King \& Levine, 1993; Wachtel, 2003; Maciejewski, 2013). Mishkin (2002) and Wachtel (2003) verified the positive relationship between the financial market and the economy's development by reducing transaction costs, better allocation of resources, and risk mitigation. The financial market regulates and balances the mismatched structure of demand and supply in the economy. Therefore, it is an essential link in organizing economic life (Bosek-Raket al., 2016). According to King and Levine (1993) and Greenwood and Jovanovic (1990), the financial system's development is crucial for economic growth, and a poorly developed financial sector may even inhibit it. Levine (1997) and Scholtens and van Wensveen (2000) believe that the financial system can positively impact economic growth through capital accumulation and technological innovation. Based on a literature review, Yousif (2002) identifies four major research trends relating to the impact of the financial market on the economy: 1) it confirms the positive dependence of economic growth on the financial sector, as stated above, 2) it does not attribute financialization to the driving force of economic growth but only to the co-existing component, 3 ) it identifies a two-way dependence between the financial sector and economic development, 4) there is no cause and effect relationship between the financial industry and the real sphere.

Kasprzak-Czelej (2010) notes that a well-developed financial system is essential for the economy, and growth processes depend on its individual functions' effectiveness. On the one hand, it is necessary for the financial system's maturity, but on the other hand, for the economy's need. The research confirms the different dependence between the financial market and economies with varying economic development levels (Piketty \& Zucman, 2014).

Dabla-Noris and Srivisal (2013) confirm that too high level of finance can harm the economy. Therefore, there is a condition associated with the degree of maturity of the financial sector that must take place to affect the economy positively. It is confirmed by Cecchetti and Kharroubi (2012), who say that financialisation contributes to economic growth only to a certain point, beyond which it is a growth slowing down factor.

The assessment of the financial sector's impact and its innovations on the real sphere was diametrically correlated with the global financial crisis 2007-2008. In the pre-crisis period, innovative technological solutions introduced into the financial market were perceived as instruments of the future, reforming financial systems and providing de facto unlimited possibilities of risk transfer and return of capital (Marshal, 2019). The crisis in the American mortgage market in 2007 strongly verified the perception of the so-called innovative solutions of the financial sector. 
These innovative and risky and, as it ultimately turned out, toxic financial solutions became the cause of the United States' financial crisis, spreading to other continents and affecting the real sphere (Głodowska, 2012; Thlon, 2011; Taylor, 2010).

This dichotomy is also visible in Babutsidze and lacopett's (2016) study, discussing the relationship between the financial sector and growth and inequality. The recent crisis has confirmed that the excessive and uncontrolled development of innovative financial products has provoked the financial market's destabilization and the entire economy (Parnell, 2020). Based on the above review, the research hypothesis verified in the paper is introduced:

H1: The excess of the financial sector over the real economy's needs is conducive to creating distortions not only in the financial market but also in the real economy.

\section{MATERIAL AND METHODS}

Data published by the World Bank (for the period up to 2017) on the financial market's depth were used to analyze the financial sector's importance. The research area included data presented for 214 countries and dependent territories and 29 depth indicators for financial institutions and the financial market. The lack of data for individual countries with selected indicators in specific years made it necessary to limit the research area to both the analysed period and the number of countries, and financial market depth indicators analysed. The research period 2000-2017, with 97 countries and five financial market depth indicators for which complete data were obtained, was considered a compromise solution that allows the broadest possible analysis. Developing analysis in any direction (period, countries, indicators) would force a significant narrowing of the research area in the other two aspects. The analysed countries included 30 highly developed countries, 58 developing countries, and nine transition countries. Among the indicators of the market and financial institutions' depth, in the relation to GDP was taken into account: bank assets, domestic credit to the private sector, deposits of the financial system, liquid liabilities, and personal credit provided by deposit banks and other financial institutions.

The market and financial institution depth indicators adopted for the analysis were used to construct a synthetic financialisation indicator. They were first of all subject to statistical verification regarding their volatility and mutual correlation to eliminate those that only slightly differed between the countries concerned and those that duplicated information. The critical value of the coefficient of variation was assumed to be 0.1 . Simultaneously, the correlation between the variables was carried out based on the reversed correlation coefficient matrix method, taking a critical value of 10 . As a result, the GDP ratio of private credit from depository banks and other financial institutions were disregarded in constructing the financialisation indicator, which showed too high a correlation with other market depth indicators and financial institutions.

In constructing the financialisation indicator, the standardised sums method was used, which allows for a linear arrangement of objects described by many different features. This method requires establishing the benchmark and anti-market development values and each country's position in the space between these values. The result is a measure with values in the range $[0,1]$. The results established for each country indicate their distance, which can be expressed in percentage points, to the ends of the range and the other coun- 
tries covered by the analysis. The values of the financialisation indicator constructed in this way for individual countries, in different years, speak of their relative position to each other.

The measure of financialisation is designed to determine the impact of the financial market's degree of development on economic growth. The economic growth has also been expressed in relative terms, using the same procedure and algorithm as for financialisation indicator. As a result, the measure describing the economic growth rate also takes values in the range $[0,1]$.

The juxtaposition of the measures of financialisation and economic growth rate makes it possible to determine their relationships. Their strength and direction have been verified for individual groups of countries, considering their economic development level. Two different ways of distinguishing between groups of countries have been adopted, as they give different results. The first is based on the division used in international statistics into highly developed, developing, and transforming (transition) countries. The second one is based on the value of GDP per capita. In this approach, the analysed countries were divided into four groups based on their location in the GDP per capita ranges determined by the first, second, and third quartiles $(x<Q 1 ; Q 1<x<Q 2 ; Q 2<x<Q 3 ; x>Q 3)$.

\section{RESULTS AND DISCUSSION}

The first proposed approach refers to the division of countries into developed, developing, and transforming countries (Figure 1). The obtained results indicate that the highest economic financialisation levels, compared to the total number of the studied countries, were recorded in developed countries (A). The calculated financing rate for them ranged from 0.022 to 0.891 , and its average value reached 0.238 . These countries achieved the highest GDP growth rate in the analysed period only once (Ireland in 2015). The slope of the trend line for this group of countries, determined for the points binding the degree of financialisation and economic growth rate, indicates a weak negative correlation. This means that the increasing level of financialisation of the economy is accompanied by a slowdown in economic growth for this group of countries.

Similar but stronger dependency has been observed for countries in transition (B). However, it should be stressed that the degree of financialisation of their economies was at a much lower level (financialisation index in the range from 0.002 to 0.131 , average 0.059). These countries recorded the highest GDP growth rate five times, and only those with the lowest level of financialisation (Armenia in 2003, 2005-2006, Belarus in 2008, and Kazakhstan in 2001). It is worth recalling that in the group of countries transforming, there were only nine countries.

An inverse relationship has been observed for developing countries (C). The calculated financing rate for them ranged from 0.003 to 0.601 , with an average of 0.114 . This group's countries recorded the highest GDP growth level in 12 out of 18 analysed years of the period 2000-2017. The slope of the trend line set for the points binding the degree of financing and economic growth rate indicates a weak positive correlation. This means that the increasing level of financialisation of the economy is accompanied by an increase in the economic growth rate for this group of countries.

A simple panel regression for such data shows, moreover, that a statistically significant negative correlation between financialisation and economic growth concerns countries in 
transition (Table 2). In other cases, although the direction of the relationship was confirmed (for developed countries), its statistical significance was not demonstrated.
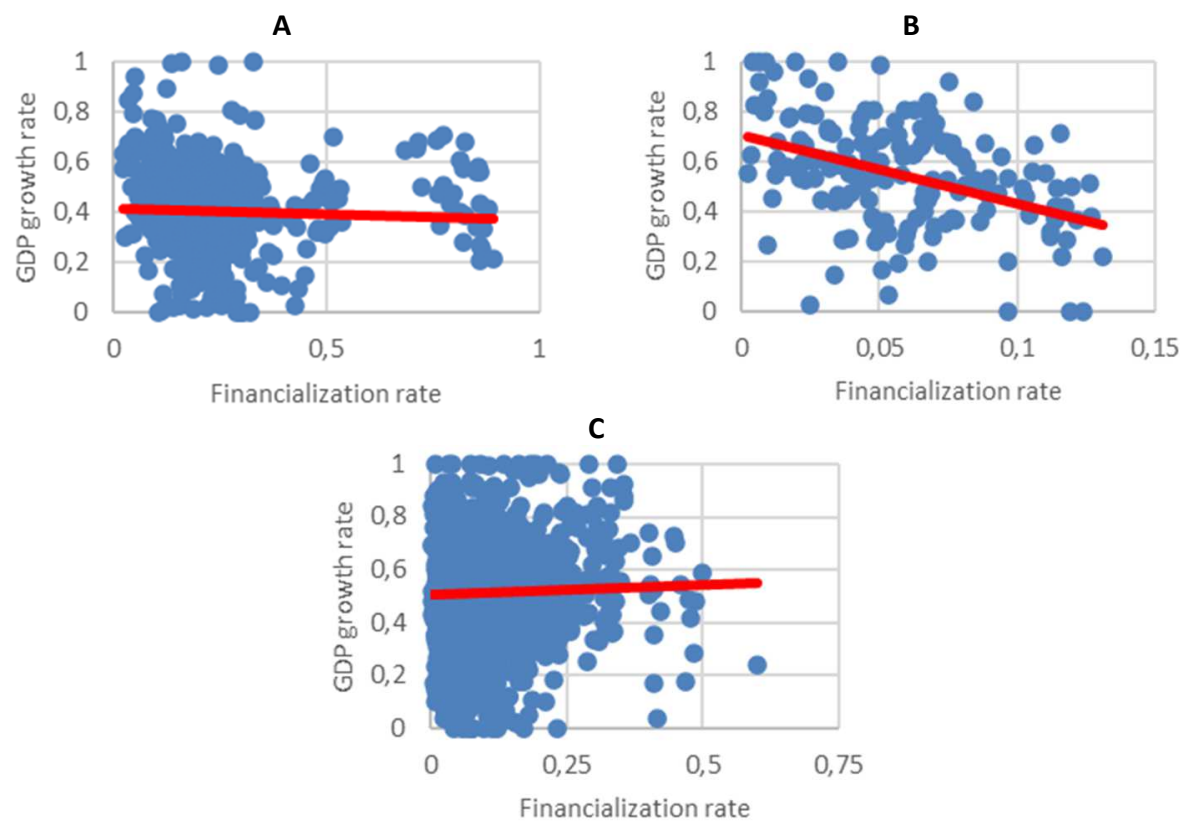

Figure 1. Relationship between the degree of financialisation of the economy and the rate of economic growth for developed (A), transition (B) and developing (C) countries in 2000-2017 Source: own calculations based on the data of World Bank (2020).

Table 2. Impact of the degree of internationalisation on the economic growth rate of developed, developing, and transition countries in the period 2000-2017

\begin{tabular}{|l|c|c|c|}
\hline \multicolumn{1}{|c|}{ Variable } & Developed countries & Transition countries & Developing countries \\
\hline Const & 0.424 & 0.681 & 0.522 \\
& $(0.0351)$ & $(0.037)$ & $(0.025)$ \\
Financialisation & -0.076 & $-2.266^{* * *}$ & -0.074 \\
indicator & $(0.145)$ & $(0.583)$ & $(0.212)$ \\
\hline LSDV R-squared & 0.207 & 0.246 & 0.210 \\
\hline Within R-squared & 0.001 & 0.091 & 0.000 \\
\hline
\end{tabular}

Note: Estimated standard errors appear in parentheses. ${ }^{* * *} p<0.01{ }^{* *} p<0.05 ;{ }^{*} p<0.10$.

Source: own calculations based on the data of World Bank (2020).

The adoption of an alternative division of countries, given their level of development, results, among other things, from the fact that the group of countries with the highest GDP per capita $(x>Q 3)$ includes countries classified in the developing group (e.g., South Korea), and the group of transition countries includes countries from as many as three groups distinguished based on quartiles (excluding countries with the highest GDP per capita).

In this perspective, the growing level of financing of the economy is accompanied by an increase in the rate of economic development in relation to countries with the 
lowest $(x<Q 1)$ and highest $(x>Q 3)$ GDP per capita (Figure 2$)$. It is despite the varying degree of financialisation of their economies. For the former group $(x<Q 1)$, the financialisation rate ranges from 0.003 to 0.332 (mean value: 0.078 ), and for the latter group ( $x>Q 3$ ) - from 0.065 to 0.891 (mean value: 0.274 ). An inverse relationship was observed for two groups of countries with a moderate level of GDP per capita, ranging from the first to the third quartile $(\mathrm{Q} 1<\mathrm{x}<\mathrm{Q} 2$ and $\mathrm{Q} 2<\mathrm{x}<\mathrm{Q} 3)$. These groups of countries are also characterized by a moderate level of financialisation of their economies. For the first of these groups $(Q 1<x<Q 2)$, the financialisation ratio is between 0.002 and 0.601 (mean value: 0.116$)$, and for the second group $\left(Q_{2}<x<Q 3\right)$ - between 0.008 and 0.446 (mean value: 0.123 ). For these two groups of countries, the slope of the trend line determined for the points binding the degree of financialisation and the rate of economic growth indicates a weak negative correlation. This means that the increasing level of the economy's financialisation is accompanied by a decrease in the economic growth rate. It can be assumed that these are representative groups $(Q 1<x<Q 3)$, as they ignore the extreme values.

A

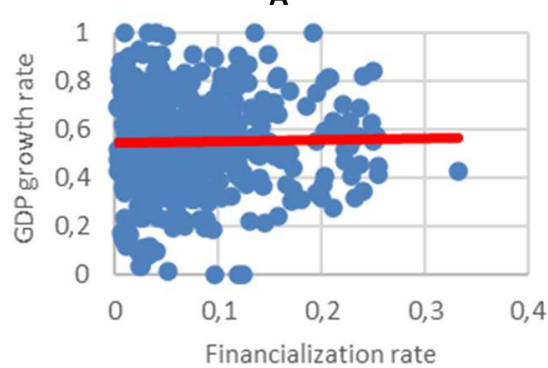

C

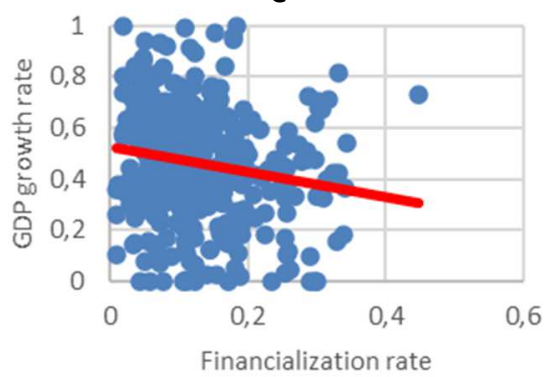

B

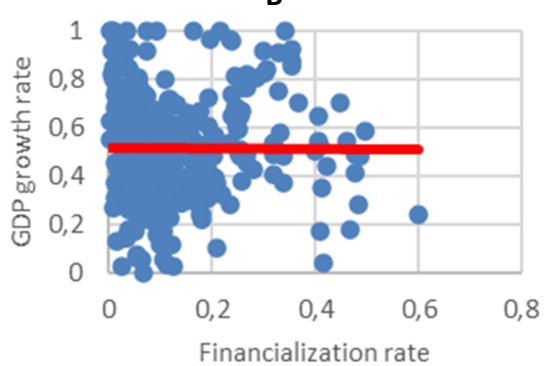

D

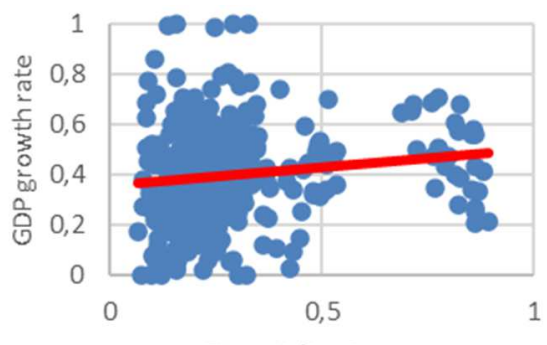

Financialization rate

Figure 2. Relationship between the degree of financialisation of the economy and the rate of economic growth for groups of countries with different levels of GDP per capita in 2000-2017 Source: own calculations based on the data of World Bank (2020).

A simple panel regression for such data shows, moreover, that a statistically significant correlation between financialisation and economic growth concerns precisely those groups of countries $(\mathrm{Q} 1<\mathrm{x}<\mathrm{Q} 2 ; \mathrm{Q} 2<\mathrm{x}<\mathrm{Q} 3)$, for which a negative correlation was shown (Table 3). In other cases, despite confirming the positive direction of the relationship, its statistical significance was not demonstrated. 
Table 3. Impact of the degree of financialisation on the rate of economic growth for groups of countries with different levels of GDP per capita in 2000-2017

\begin{tabular}{|c|c|c|c|c|}
\hline \multirow{2}{*}{ Variable } & \multicolumn{4}{|c|}{ Groups of countries with different levels of GDP per capita } \\
\hline & $x<Q 1$ & $\mathrm{Q}_{1}<\mathrm{x}<\mathrm{Q} 2$ & $Q_{2}<x<Q 3$ & $x>Q 3$ \\
\hline Const & $\begin{array}{c}0.532 \\
(0.0327)\end{array}$ & $\begin{array}{c}0.606 \\
(0.036)\end{array}$ & $\begin{array}{c}0.601 \\
(0.040)\end{array}$ & $\begin{array}{c}0.349 \\
(0.041)\end{array}$ \\
\hline $\begin{array}{l}\text { Financialisation } \\
\text { indicator }\end{array}$ & $\begin{array}{c}0.215 \\
(0.397) \\
\end{array}$ & $\begin{array}{c}-0.774 * * \\
(0.307) \\
\end{array}$ & $\begin{array}{c}-1.103^{* * *} \\
(0.317) \\
\end{array}$ & $\begin{array}{c}0.185 \\
(0.148) \\
\end{array}$ \\
\hline LSDV R-squared & 0.127 & 0.225 & 0.234 & 0.249 \\
\hline Within R-squared & 0.001 & 0.015 & 0.029 & 0.004 \\
\hline
\end{tabular}

Note: Estimated standard errors appear in parentheses. ${ }^{* * *} p<0.01{ }^{* *} p<0.05{ }^{*} p<0.10$.

Source: own calculations based on the data of World Bank (2020).

\section{CONCLUSIONS}

Previous research show that the direct or indirect effects of the industrial revolution 4.0 are felt in all socio-economic spheres. An excellent example of this is the financial market and its impact on the real economy, precisely due to the influence of 4IR. Empirical research has shown the different nature of the relationship between countries' financialisation and economic growth at different development levels. Both presented classification approaches of countries indicate a statistically significant negative impact of financialisation on selected groups of countries' economic growth rates. It applies to countries in transition and those whose economic development level is an average. In countries with the highest economic development level, there has been no statistically significant financialisation impact on the economic growth rate. The results obtained suggest a weak positive correlation between these variables.

Therefore, the analysis results did not confirm what Levine et al. (2000) postulated that more significant development of the financial sector increases the economy's growth potential. It has only shown that, for the countries with the highest levels of economic development, there is no reason to argue that too high level of financial sector development slows down economic growth, as Arcand et al. (2012) and Dabla-Norris and Srivisal (2013) wrote. The study has shown that countries with the highest economic development level have a high level of financialisation of their economies.

However, the research has shown that the development of the financial sector, which is detrimental to economic growth, occurs in transition countries and with an average economic development level. The level of financialisation of the economy there is lower too.

The analysis carried out is associated with some limitations, including a limited supply of comparable data and many simplifications, such as generalising the GDP growth rate for the economy as a whole. In subsequent studies, it would be worthwhile differentiating in this regard, at least for the productive and service sectors. One of the effects of financialisation may be a change in the structure of the GDP created.

Despite these limitations, the study should motivate some thoughts on connecting the financial market with the real economy. Thus, this study may have application values for policymakers and financial market participants. Based on the observations made, certain 
conclusions can be drawn to shaping the rules for the financial market's functioning and its implication for the economy.

\section{REFERENCES}

Alan, N., Gupta, L., \& Zameni, A. (2019). Fintech and Islamic Finance. Berlin: Springer International Publishing.

Arcand, J.-L., Berkes, E., \& Panizza, U. (2012). Too much finance? (IMF Working Paper, WP/12/161, 1-49). Washington, DC: Author.

Babutsidze, Z., \& lacopetta, M. (2019). The Emergence of Money: Computational Approaches with Fully and Boundedly Rational Agents. Computiational Economics. DOI:10.1007/s10614-019-09887-x

Bayón, B.P., \& Vega, L.G. (2018). An Outlook on the Role of Finance Regulation under the Fourth Industrial Revolution. Archives of Business Research, 6(10), 423-434.

Bilan Y., Rubanov, P., Vasylieva, T., \& Lyeonov S. (2019). The Influence of Industry 4.0. on the Financial Services: Determinants of Alternative Finance Development. Polish Journal of Management Studies, 19(1), 70-93.

Booth, A., Sutton, A., \& Papaioannou, D. (2016). Systematic approaches to a successful literature review. London: Sage.

Bosek-Rak, D., Kozłowski, Ł. K., \& Muszyński, M. (2016). Ewolucja postrzegania przez nauki ekonomiczne wpływu sektora finansowego na wzrost gospodarczy przed i po kryzysie finansowym. Kwartalnik Prawo - Społeczeństwo - Ekonomia, 4, 4-15.

Cecchetti, S.G, \& Kharroubi, E. (2012). Reassessing the impact of finance on growth (BIS Working Paper 381). Bessel: Bank for International Settlements.

Dabla-Norris, E. \& Srivisal, N. (2013). Revisiting the link between finance and macroeconomic volatility(IMF Working Paper, WP/13/29, 1-35). Washington, DC: Author.

Dai, J., \& Vasarhelyi, M.A. (2017). Toward Blockchain-Based Accounting and Assurance. Journal of Information Systems: Fall, 31(3), 5-21.

Davis, L.S., \& Sener, F. (2012). Intellectual Property Rights, Institutional Quality and Economic Growth. Journal of International Commerce, Economics and Policy, 3(1), 1-28. DOI: $10.1142 /$ S1793993312400054

Dębski, W., \& Bujnowicz, I. (2007). Wzajemne zależności wzrostu gospodarczego i rozwoju systemu finansowego w Polsce - analiza symulacyjna. Acta Universitatis Lodziensis. Folia Oeconomica, 209, 57-70.

Dabla-Noris, E., \& Srivisal, N. (2013). Revisiting the Link Between Finance and Macroeconomic Volatility (IMF Working Paper WP/13/29). Washington, DC: Author.

Frame, W.S., \& White, L.J. (2004). Empirical Studies of Financial Innovation: Lots of Talk, Little Action?. Journal of Economic Literature, 42(1), 116-144.

Głodowska, A. (2012). Geneza i przebieg kryzysu gospodarczego lat 2008-2009. In S. Wydymus, E. Bombińska, \& B. Pera (eds.), Handel międzynarodowy w warunkach kryzysu gospodarczego. Implikacje dla Polski (pp. 55-78). Warszawa: CeDeWu.

Głodowska, A. (2019). Międzynarodowe porównania przedsiębiorczości krajowej w Unii Europejskiej. Determinanty i efekty w perspektywie przedsiębiorczości międzynarodowej. Warszawa: PWN.

Greenwood, J., \& Jovanovic, B. (1990). Financial Development, Growth, and the Distribution of Income. Journal of Political Economy, 98 (5), 1076-1107.

Iansiti, M., \& Lakhani, K.R. (2017). The Truth about Blockchain. Harvard Business Review 95(1), 118-127. 
Judge, K. (2012). Fragmentation Nodes: A Study in Financial Innovation, Complexity, and Systemic Risk. Stanford Law Review, 64(3). Retrieved from: http://www.stanfordlawreview.org/wp-content/uploads/sites/3/2012/04/Judge-64-Stan-L-Rev-657.pdf on March 17, 2020.

Karabay, M., \& Cağil, G. (2017). Examining Financial Innovation and Performance in Financial Sector: A Comprehensive Review of Emerging Markets. In U. Hacioglu, H. Dincer, \& N. Alay-oğlu (Eds.), Global Business Strategies in Crisis. Strategic Thinking and Development (pp. 353-369). Berlin: Springer.

Kasprzak-Czelej, A. (2010). Wpływ rozwoju systemu finansowego na wzrost gospodarczy. Annales Universitatis Mariae Curie-Skłodowska. Sectio H, Oeconomia, 44(2), 17-30.

Kimani, D., Adams, K., Attah-Boakye, R., Ullah, S., Frecknall-Hughes, J., \& Kim, J. (2020). Blockchain, business and the fourth industrial revolution: Whence, whither, wherefore and how?. Technological Forecasting and Social Change, 161. DOI:10.1016/j.techfore.2020.120254

King, R., \& Levine, R. (1993). Finance and Growth: Schumpeter might be right. Quarterly Journal of Economics, 108(3), 717-737.

Koizumi, S. (2019). The Light and Shadow of the Fourth Industrial Revolution. In S. Lechevalier (ed.), Innovation Beyond Technology (pp. 63-86). Berlin: Springer.

Lee, I., \& Shin, Y.J. (2018). Fintech: Ecosystem, business models, investment decisions, and challenges. Business Horizons, 61(1), 35-46.

Levine, R. (1997). Financial Development And Economic Growth: Views And Agenda. Journal of Economic Literature, 35(2), 688-726.

Levine, R., Loayza, N., \& Beck, T. (2000). Financial intermediation and growth: Causality and causes. Journal of Monetary Economics, 46(1), 31-77.

Li, J.P., Naqvi, B., Rizvi, S.K.A., \& Chang, H.L. (2021). Bitcoin: The biggest financial innovation of fourth industrial revolution and a portfolio's efficiency booster. Technological Forecasting and Social Change, 162. DOI: 10.1016/j.techfore.2020.120383

Liu, C. (2017). International Competitiveness and the Fourth Industrial Revolution. Entrepreneurial Business and Economics Review, 5(4), 111-133. DOI:10.15678/EBER.2017.050405

Lucas, R.E. (2009). Trade and the Diffusion of the Industrial Revolution. American Economic Journal Macroeconomics, 1(1),1-25.

Maciejewski, M. (2013). Polska na tle kryzysu strefy realnej gospodarki krajów Unii Europejskiej. Finanse, Rynki Finansowe, Ubezpieczenia, 57, 331-343.

Marshall, A.G. \& Chossudovsky, M. (2019). The Global Economic Crisis: The Great Depression of the XXI Century. Stockton: Global Research.

Mishkin, F. (2002). Ekonomika pieniqqdza, bankowości i rynków finansowych. Warszawa: PWN.

Nowiński, W., \& Kozma, M. (2017). How Can Blockchain Technology Disrupt the Existing Business Models?. Entrepreneurial Business and Economics Review, 5(3), 173-188. http://doi.org/10.15678/EBER.2017.050309

Pernell, K. (2020). Market governance, financial innovation, and financial instability: lessons from banks' adoption of shareholder value management. Theory and Society, 49, 277-306. DOI:10.1007/s11186-020-09389-y

Piketty, T., \& Zucman, G. (2014). Capital is Back: Wealth-Income Ratios in Rich Countries 1700-2010. The Quarterly Journal of Economics, 129(3), 1255-1310.

Philbeck, T., \& Davis, N. (2019). The Fourth Industrial Revolution: Shaping A New Era. Journal of International Affairs, 72, 17-22. 
Paskevicius A., \& Keliuotyte-Staniuleniene G. (2018). The evaluation of the impact of financial technologies innovations on CEECs capital markets. Marketing and Management of Innovations, 3, 3-21.

PwC (2014). Industry 4.0 Chancen und Herausforderungen der vierten industriellen Revolution. PwC Strategy \& GmbH. Retrieved from https://www.strategyand.pwc.com/media/file/Industrie-40.pdf on August 31, 2019.

Rymarczyk, J. (2020). Technologies, Opportunities and Challenges of the Industrial Revolution 4.0: Theoretical Considerations. Entrepreneurial Business and Economics Review, 8(1), 185-198. DOI:10.15678/EBER.2020.080110

Scholtens, B., \& van Wensveen, D. (2000). A critique on the theory of financial intermediation, Journal of Banking \& Finance, 24(8), 1243-1251

Schumpeter, J. (1960). Teoria Rozwoju Gospodarczego. Warszawa: PWN.

Schwab K. (2015). The Fourth Industrial Revolution: What It Means and How to Respond. Foreign Affairs. Retrieved from: https://www.foreignaffairs.com/articles/2015-12-12/fourth-industrialrevolution on May 2020.

Schwab, K. (2016). The fourth industrial revolution. New York, NY: Crown Business.

Schwab, K. \& Davis, N. (2018). Shaping the Future of the Fourth Industrial Revolution. Londyn: Portfolio Penguin.

Su, Ch.W., Qin, M., Tao, R., Shao, X.F., Albu, L.L., \& Umar, M. (2020). Can Bitcoin hedge the risks of geopolitical events?. Technological Forecasting and Social Change, 159(C), 120182. DOI: 10.1016/j.techfore.2020.120182

Taylor, J.B. (2010). Zrozumieć kryzys finansowy. Przyczyny, skutki, interpretacje. Warszawa: PWN.

Thampanya, N., Nasir, M.A., \& Duc Huynh, T.L. (2020). Asymmetric correlation and hedging effectiveness of gold \& cryptocurrencies: From pre-industrial to the 4 th industrial revolution. Technological Forecasting and Social Change, 159, [120195]. DOI:10.1016/j.techfore.2020.120195

Thlon, M. (2009). Proces sekurytyzacji aktywów w kontekście kryzysu na rynku kredytów subprime, e-Finance, 2.

Wachtel, P. (2003). How much do we really know about Growth and Finance. Federal Reserve Bank of Atlanta Economic Review, 33-47.

Wang, L., Luo, G-I., Sari, A., \& Shau, X-F. (2020). What nurtures fourth industrial revolution? An investigation of economic and social determinants of technological innovation in advanced economies. Technological Forecasting \& Social Change, 161, 1-7.DOI: 10.1016/j.techfore.2020.120305

World Bank (2020). Global Financial Development Database. Retrieved March, 2020 from https://www.worldbank.org/en/publication/gfdr/data/global-financial-development-database on July $21,2020$.

Yousif, K.A.Y. (2002). Financial development and economic growth. Another look at the evidence from developing countries. Review of Financial Economics, 11(2), 131-150. 


\section{Authors}

The contribution share of authors is equal and amounted to $50 \%$ for each of them.

\section{Marek Maciejewski}

Associate Professor in the Department of International Trade, PhD in economics (2005), Habilitated doctor (dr hab.) in economics and finance (2013), author of the publications on international trade and international entrepreneurship. Scientific secretary of the journal 'International Entrepreneurship Review'. His research interests include international trade, international finance, international entrepreneurship.

Correspondence to: Prof. Marek Maciejewski PhD, Cracow University of Economics, ul. Rakowicka 27, 31-510 Kraków, Poland, e-mail: maciejem@uek.krakow.pl

ORCID (1) http://orcid.org/0000-0003-1343-3764

\section{Agnieszka Głodowska}

Associate Professor in the Department of International Trade, PhD in economics (2009), Habilitated doctor (dr hab.) in economics and finance (2013), author of the publications on international business and international entrepreneurship, member of editorial boards of 'Entrepreneurial Business and Economics Review' (Scopus, ESCI WoS), 'International Journal of Managerial Studies and Research' (USA), 'International Entrepreneurship Review' (Poland). Her research interests include international entrepreneurship, finance and risk in international business.

Correspondence to: Prof. Agnieszka Głodowska PhD, Cracow University of Economics, ul. Rakowicka 27, 31-510 Kraków, Poland, e-mail: glodowsa@uek.krakow.pl

ORCID (1) http://orcid.org/0000-0002-5317-8625

\section{Acknowledgements and Financial Disclosure}

This project has been financed by the Ministry of Science and Higher Education within the "Regional Initiative of Excellence" (RID) Programme for 2019-2022. Project no. 021/RID/2018/19. Total financing: $11,897,131.40$ PLN.

\section{Copyright and License}

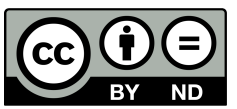

This article is published under the terms of the Creative Commons

Attribution - NoDerivs (CC BY-ND 4.0) License

http://creativecommons.org/licenses/by-nd/4.0/

Published by Cracow University of Economics - Krakow, Poland 